\title{
WHEN GERMAN SERIES GO GLOBAL
}

\author{
INDUSTRY DISCOURSE ON THE PERIOD \\ DRAMA DEUTSCHLANDANDITS \\ TRANSNATIONAL CIRCULATION
}

Florian Krauß

University Siegen

krauss@medienwissenschaft.uni-siegen.de

\begin{abstract}
The article takes a closer look at the current industry discourse on the transnational circulation of German series. At its centre is a case study of the 1980s period drama Deutschland (2015-2020), based on interviews with key executives and creatives. What is it that makes such ready-made TV fiction go transnational, according to the involved practitioners and in this specific case? Textual factors in particular are examined, such as the thematic and aesthetic extension of the historical-political 'event' miniseries through Deutschland. Furthermore, the article explores factors in respect to production, including screenwriting and financing, in the context of the dynamic TV landscape in Germany and Europe.
\end{abstract}

Keywords: German television, television series, television production, global television, television scriptwriting, European TV series, period drama, German TV fiction

\section{Introduction}

'Showrunners and Antiheroes - What Does the German Series Need for International Success?'1 was the title of an industry panel held adjacent to the 2015 Berlin International Film Festival, or Berlinale, at which the first season of the espionage coming-of-age drama Deutschland (2015-2020) premiered. Also during the festival, its sale to the US - a market particularly valued in a Western, transnational context - was announced. The unofficial Berlinale event, where industry attendees applauded this news, and the following media coverage on the US export of Deutschland $83,{ }^{2}$ are just a few examples of the recent, ongoing discourse on the transnational circulation of German TV drama. In the last decade, similar discussions have been raised in the television industry and trade magazines, ${ }^{3}$ as well as in television criticism and the feature pages of newspapers. ${ }^{4}$ These negotiations have continued earlier debates on German cinema and its arguable lack of 'international' appeal ${ }^{5}$ and have been accompanied by an evaluation discourse on socalled quality TV. Besides German-language academia ${ }^{6}$ and the feuilleton, ${ }^{7}$ German TV professionals have taken up the discussion of such television and the Anglicism linked to it. ${ }^{8}$ Public statements by practitioners ${ }^{9}$ and papers that circulate in the industry ${ }^{10}$ indicate that 'quality TV' has been especially understood through textual characteristics of certain US series and through their reported production methods, which are said to differ from the ones used in Germany. The above-quoted title of the panel certainly reflects these emphases by containing two examples: 'showrunners', describing the leading writer-producers with 'managerial oversight', ${ }^{11}$ on the side of production; and 'antiheroes', as a textual feature. 
With a corresponding focus on production-specific and textual aspects, my article takes a closer look at the current industry discourse on the transnational circulation of German series. At its centre is a case study of Deutschland. What is it that makes such ready-made fictional television go transnational, according to the involved practitioners and in this specific case? This show, which follows an East German spy in the West German Armed Forces during the Cold War, is a particularly fruitful example to explore this question. Deutschland has helped to initiate a taste for German TV fiction in English-speaking markets and potentially kickstarted what has been termed a 'German TV Renaissance' by the Guardian. ${ }^{12}$ Furthermore, the series has transnationalised in its own course of development, as we will see.

Methodologically, this article relies on expert interviews. ${ }^{13}$ Between 2016 and 2019, I conducted them with key executives and creatives involved in Deutschland: Jörg Winger, the leading writer-producer, or creator; ${ }^{14}$ Ulrike Leibfried, the commissioning editor for the commercial channel RTL for its first season; ${ }^{15}$ Joachim Kosack, CEO of the production house UFA; ${ }^{16}$ and two of the directors, Edward Berger ${ }^{17}$ and Florian Cossen. ${ }^{18}$ Additionally, and in connection with a broader production study, ${ }^{19}$ my participant observations at multi-day industry workshops ${ }^{20}$ on series production (from 2015 to 2019) are taken into account. These observations are a vital complement to the interviews, as they ensure the researcher does not (co)produce the analysed industry discourse too much. Furthermore, Winger and others discussed Deutschland in lectures at these events and helped the researcher remain up to date regarding this series' advancement. In interpreting the interviews with methods suggested by Ulrike Nagel and Michael Mauser ${ }^{21}$ and Hanne Bruun, ${ }^{22}$ and, more generally, with perspectives from critical media industry and production studies, ${ }^{23}$ the protocols on the participant observations are also used.

The article first locates Deutschland in the broader TV fiction industry in Germany. Subsequently, textual factors are examined which, according to interviewees, have helped Deutschland travel to other markets. Finally, factors in respect to production, including screenwriting and financing, are explored. Thus, the paper analyses the case study in several directions, which corresponds to a multidimensional series analysis influenced by the circuit of culture ${ }^{24}$ and related concepts, ${ }^{25}$ even though the perspective of the practitioners remains firmly foregrounded. The textual and productionspecific aspects indicate different areas in which border crossings and exchange processes - summarised under the term transnationalisation ${ }^{26}$ - can take place, including in divergent, contrary ways.

In this context, the interpretations of interviews with television professionals can be linked to the dimensions of global flow, as described by Arjun Appadurai. ${ }^{27}$ Although Appadurai has in mind the metaprocesses of globalisation when delineating mediascapes, technoscapes, ideoscapes, financescapes and ethnoscapes, ${ }^{28}$ one can also find such routes and practices of transnationalisation in the single case study explored here. For instance, some production methods and cultures approached in this project can be seen as transnational practices and techniques, and in this sense considered technoscapes, while the transnational exchange of involved people points to ethnoscapes. Appadurai's '-scapes' also provide a productive theoretical basis for the analysis of ready-made content from Germany, because they help keep possible contradictions and aspects of localisation in mind. 'Globalization involves the use of a variety of instruments of homogenization ... that are absorbed into local political and cultural economies', Appadurai states. ${ }^{29}$ Concurrent to its transnational circuit and the influence of 'quality TV' series from the US on it, Deutschland is rooted in such a local context, which, first of all, requires closer inspection.

\section{The TV Fiction Industry in Germany}

For certain, the German TV fiction industry cannot be understood as a completely closed, solely national space. On the contrary, overlaps with other producing countries are obvious, for instance because of institutional involvement in transnational media groups, ${ }^{30}$ through co-financing and co-production, ${ }^{31}$ in relation to format adaptations in the context of an Anglo-American-dominated TV format trade ${ }^{32}$ and through exports. German TV fiction has been sold to non-German markets in several cases other than Deutschland: the long-running soap opera Sturm der Liebe (Storm of Love, 2005-), 
licensed to twenty stations worldwide, and the crime procedural Derrick (1974-1998) are well-known examples. Heimat (especially Heimat - Eine deutsche Chronik [A Chronicle of Germany], 1984) and Berlin Alexanderplatz (1980) were critically acclaimed beyond West Germany as well. However, a substantial part of German TV fiction serves primarily a national, or at least German-speaking, audience. Due to its relatively large size, the need for further export sales is lower than in smaller European countries. Edward Berger, one of the directors of the first season of Deutschland (Deutschland 83), spoke in the interviews, with a critical undertone, of 'a complacent market'.

In the production study on Deutschland, again and again the relation to the national or German-speaking market was reflected when the interviewees discussed broader tendencies and characteristics of German TV fiction. Joachim Kosack, producer and managing director of UFA (one of German TV's biggest production houses), suggested an initial approach to series production in Germany that separates it into four fields: first, 'industrial series', with 250 episodes per year and a fixed production method based on the division of labour; ${ }^{33}$ second, the 'weekly series' with twenty-six, and in exceptional cases fifty, annual episodes and a set core team; third, the 'local primetime series', with thirteen episodes per year and a clear focus on national broadcasting slots; and finally 'high-end' productions. ${ }^{34}$ The latter is characterised by higher budgets and a link to the tradition of the 'event film'. Such hybrids of television films and miniseries, consisting of two or three ninety-minute parts and mostly dealing with historical issues, have been associated in particular with the production company UFA Fiction, as well as its former subsidiary teamWorx, ${ }^{35}$ and have frequently managed to be broadcast in several countries (see, e.g., Die Flucht [March of Millions], 2007, or Dresden, 2006).

Although omissions can be found in Kosack's list (such as long-running, somewhat serialised collections of TV films in the style of Tatort [1970-] ${ }^{36}$ and low-budget series from emerging talents), it proves helpful in classifying and locating Deutschland. At first glance, this project clearly belongs to the 'high-end' segment, for which foreign sales are increasingly an economic necessity, according to Kosack. But to some extent, it also fits with the more local and regularly produced series, as Jörg Winger and other involved practitioners came from the long-running crime procedural SOKO Leipzig (Leipzig Homicide, 2001-), one of now ten spin-offs of the German-Austrian format SOKO (1978-), which reflects Germany's federalist structures and regionalism in some TV content.

Kosack attributed the merging of different production fields and people to restructuring within the UFA production company and to collaboration between individuals, corresponding to the tendency towards personalisation in TV professionals' talk or 'industrial self-theorizing'. ${ }^{37}$ The personal networks that likely led to the emergence of Deutschland also include individual decision makers on the side of RTL, an advertising-financed broadcaster which, like UFA, belongs to Bertelsmann's RTL Group. Coinciding with the development of the screen idea for Deutschland, Frank Hoffmann, then the new head of RTL, wished for an event programme such as Unsere Mütter, unsere Väter (Generation War, 2013). This frequently criticised - but in Germany also acclaimed - three-part drama about a group of five German youths and their different experiences during World War II was a big audience hit on public-service channel ZDF in 2013, and sold to various countries. In reference to this show, several interviewees indicated textual characteristics and traditions which might also have helped Deutschland to go transnational.

\section{Textual Factors for Transnational Circulation}

Through the production company UFA Fiction and the at least indirect influence of Generation War, Deutschland ties in with the multipart 'historical-political event film', ${ }^{38}$ which frequently concerns National Socialism in the arguably very problematic form of melodramas with 'ordinary' Germans as protagonists. ${ }^{39}$ Kosack argued that the success of Generation War in different countries paved the way for Deutschland's transnational travel. Florian Cossen, one of two directors of its second season, Deutschland 86, more generally ascribed a 'narrative power' to Generation War, which might have helped to initiate the rise of 'quality TV' series with greater transnational compatibility. But the immense criticism that Generation War met with, especially in Poland ${ }^{40}$ and the US, ${ }^{41}$ and the accusation of revisionism could 
of course also be interpreted as a problematic perception of German television abroad. In this respect, such mediascapes and ideoscapes, beyond just the UFA company, might not altogether have helped promote the transnational circulation of German TV drama.

Even among the interviewed production members of Deutschland, there emerged somewhat critical voices on this kind of fictional history television on National Socialism. Partly, the fear of a thematic narrowing was expressed - which is by no means a new or television-specific discussion, if we consider West German film history. 'Movies dealing with Nazi themes had been of the largest export successes', as Robert C. Reimer et al. state, ${ }^{42}$ but they often also met with criticism. Deutschland points to a thematic extension, with a focus on the period of the Cold War and the division of Germany in the 1980s, although especially the latter has become a frequent subject of contemporary television films and series from Germany (e.g. Weissensee, 2010-2018; Preis der Freiheit [Prize of Freedom], 2019; Wendezeit [Time of Change], 2019).

To some extent, Deutschland also stands for a different narrative and aesthetic approach by avoiding the claim of realism and authenticity that still dominated Generation War and many of its paratexts. According to Jörg Winger, producer and creator of Deutschland, East German fashion magazines from the 1980s and the Coen brothers' spy comedy Burn after Reading (2008) provided inspiration for the show's stylised, only partly realistically depicted setting. Instead of historical accuracy, the focus turned more to pop-cultural references ${ }^{43}$, that are arguably easier for non-German viewers to decode (e.g. Nena's song '99 Luftballons', featured several times in season one).

However, according to Winger, the corresponding reconfiguration of the historical event/high-end miniseries from UFA was not centrally planned. This supposition corresponds to the tendency that 'industrial self-theorizing and sense making frequently pose as unintentional and effacing', as John Thornton Caldwell has argued. ${ }^{44}$ At the very least, Winger took into account the contrast to other German period dramas when he wondered if lightness and popular culture did not go over well with parts of the German audience, which may prefer 'history' and 'a certain gravity and seriousness'. Here, Winger also discussed possible reasons why audience ratings for broadcasting on RTL in 2015 fell short of expectations.

On the textual level, Deutschland also differs from the previous 'historical-political event film' 45 or miniseries by having more episodes and being more serialised. In this respect, the show probably has become more transnationally connectable by contrasting strongly with the single TV film. The latter still forms a core component of German television fiction today. ${ }^{46}$ Some TV professionals involved in Deutschland considered the single TV film to be a separate route, a Sonderweg, and a problematic one, since it is considered outdated. Furthermore, they argued that this format deviates from the standards of other TV markets, making it difficult to connect to them and hampering an ongoing serial dramaturgy.

For years, such storylines spanning across several episodes have been a point of discussion in the German TV industry. Often broadcasters approached them only through the well-established two- or three-part 'event' miniseries with ninety-minute episodes, which again reflects the relevance of TV films in German TV fiction. Even with Deutschland, these traditions are indicated if one takes the distribution, excepting direct textual characteristics, into account. On RTL, the first season was broadcast in double episodes, a scheduling strategy used for other German and European serials (see, e.g., the political drama Die Stadt und die Macht [The City and the Power], 2016, and the co-production West of Liberty, 2019). In this way, the serial is somehow turned back into an 'event' television film with ninety-minute parts. Regarding the first season, Deutschland 83, some interviewees reflected critically on such scheduling practices, revealing a certain tension between, on the one hand, transnationally circulating 'quality TV' and, on the other, linear, nationally shaped distribution and programme patterns.

Linked to the overarching serial narration, in Deutschland, the goal of a 'quality TV' serial was pursued. Winger's anecdotal assessment that 'this kind of quality series' has not existed in Germany before can surely be countered by various examples, especially from public-service broadcasting (e.g. Im Angesicht des Verbrechens [In the Face 
of Crime], 2010, ${ }^{47}$ and KDD - Kriminaldauerdienst [Berlin Crime Squad], 2007-1048). Nevertheless, various production stakeholders voiced that Deutschland was a deliberate attempt to implement 'quality TV' in German television. During a lecture at an industry workshop, Anja Käumle, director of PR and marketing at UFA, who recently joined the German Netflix team explicitly pointed out that in her public relations work on the show, she took up the press topic of whether 'we Germans' can do 'quality TV'. In this context, the 'quality TV' serial as an American concept and transnational television trend has become a growing part of the national discourse, reminiscent of Appadurai's argument mentioned above that, in processes of globalization, "instruments of homogenization ... are absorbed into local political and cultural economies". ${ }^{49}$ In the case discussed here, the local cultural economy particularly relates to the commercial broadcaster RTL. It is associated more with 'trash' than with 'quality' TV in the public media discourse. ${ }^{50}$ Deutschland was intended to overturn this existing image, not least for the interests of advertisers, who reward an attractive environment when booking commercials. However, Ulrike Leibfried, commissioning editor for the first season at RTL, also ascribed to the series an orientation towards mainstream tastes and popularity. Textually speaking, such reasons can also be discussed as to why Deutschland went transnational: arguably it was the show's mainstream appeal and its 'light moments' (appreciated, for example, in a New York Times review) ${ }^{51}$ that proved to be transnationally connectable, in addition to the tendencies for overarching storylines and serial 'quality TV'.

The 'quality TV' serial and its discursive negotiation in Germany remained important when practitioners involved in Deutschland discussed their roles as well as broader production conditions. It is also in this area of negotiation where one might find further factors enabling German TV drama to travel.

\section{Production Factors for Transnational Circulation}

In the industry discourse on German 'quality TV', practitioners often engage in negotiations about which (and if) production modes lead to a higher 'quality', therefore enabling the transnational circulation of German serials. Similar to the text-based discussion, professionals have often identified deficits in relation to production. ${ }^{52}$ The position of writers especially has received much criticism ${ }^{53}$ and has been reflected upon critically in approaches to the showrunner and the writers' room. ${ }^{54}$ As in other European contexts, ${ }^{55}$ these production techniques - or technoscapes, in Appadurai's terminology - have been more recently negotiated in the German TV fiction industry. Showrunners as top writer-producers are supposed to guarantee coherence, especially in respect to dramatic continuity, which is why the industry discourse has linked this role to the overarching narration of 'quality TV' serials.

Such issues and priorities were clearly reflected in the interviews with production team members of Deutschland. Jörg Winger in particular brought up the issue of the showrunner by giving himself this 'elevated' job title. With the Deutschland project, an adaptation of the showrunner role can be discussed since Winger, the producer of numerous SOKO Leipzig episodes, and his American wife, Anna Winger, the head writer of the series and with experience as a novelist and journalist, combine the competences of writing and producing. Still, other production members sometimes questioned this categorisation, saying that Anna and Jörg Winger were hardly present on set, whereas the showrunner usually would be. "Jörg Winger was a producer, Anna Winger was a writer and I was a director. That would be a correct description of our jobs", Edward Berger summed up. ${ }^{56}$

Whatever the actual status of the showrunner for Deutschland, the interviewees touched upon this production mode again and again. Starting from that issue, Jörg Winger addressed the distribution of power in production networks, which, in his view, has to change for Germany to catch up with other countries in terms of 'quality TV' series. In particular, he pointed toward the often weak status of scriptwriters and reflected critically upon the 'special position' of the director in German TV fiction, which he traced back to the tradition and importance of the single TV film. By contrast, he said, series are much more of a 'writer's medium'. "The director is a very central creative in TV series production, too, but usually not the final decision maker, as in most films", Winger explained in an email. ${ }^{57}$ Florian 
Cossen, director of Deutschland 86, said that he had not yet reached a conclusion on the subordination of his guild's role in the wake of the turn towards the showrunner. More clearly than his predecessor Berger, Cossen agreed that Deutschland was produced "on the American model ... according to the showrunner principle", which is why he concentrated only on the shooting in this project. Berger may have another perspective on the production process because, after Deutschland 83, he started to direct episodes of the British-American project Patrick Melrose (2018) and the American The Terror (2018-), for which the showrunner role may be more significant. But it is also possible that the work on Deutschland has gradually moved closer to the 'showrunner principle' identified by Cossen for the second season, since the project is also said to have changed in terms of the time spent together in the writers' room.

Often, this collective writing arrangement has been identified as a possible answer as to how series from Germany could gain in 'quality' and become more successful transnationally. ${ }^{58}$ However, an exclusive commitment of several writers over a longer period of time and their actual collaboration in a room have for a very long time remained the exception in German TV production, at least beyond the story departments of 'industrialised' daily soap production. ${ }^{59}$ But in the 'high-end' area, as Kosack named it, tendencies towards more collaborative scriptwriting and the more comprehensive involvement of screenwriters are now clearly visible, as the Deutschland case study can illustrate.

According to the interviewees, the alleged writers' room for the first season consisted of the German-American couple Anna and Jörg Winger and four additional writers of different nationalities, accounting for why ethnoscapes can be discussed in the screenwriting process to some extent. Winger called two of the writers 'old hands' and two 'quite inexperienced'. He stated that a junior producer and an intern were also involved in the collaborative development. The integration of junior staff is also known from other approaches to the writers' room in Germany and seems to be motivated above all by economic factors and the hope for 'fresh' ideas. ${ }^{60}$ As in other projects, in the case of Deutschland 83, the writers came together for several multi-day meetings only. For the second season, Deutschland 86 , the time frame of this joint work was said to have been temporarily extended.

Before the first so-called writers' room meeting, Anna Winger, with the cooperation of her husband, had already written a spec script and rough storylines for seven episodes. During collaborative development later on, the additional four writers partly acted as advocates of individual characters and were responsible for different special subjects. Each individually wrote the first and the second drafts for the same two episodes. But, in the end, Anna Winger took over, writing all final drafts. According to Patricia Phalen and Julia Osellame's study of the writers' room in Hollywood, that situation is 'not an optimum scenario, given the production demands on the showrunner's time'. ${ }^{61}$ But for German series, which usually have fewer episodes than their American counterparts, such a return to the head writer seems to be common, if we look beyond the case study discussed here to other projects, such as, for instance, Dark (2017-2020).

In the end, economic factors are the main reason why the writers' room and probably also the showrunner have been practised in only a rudimentary form for Deutschland and other German series productions. ${ }^{62}$ At the observed industry workshops, again and again, limited production resources in the German television industry were highlighted. In the case of Deutschland, at least from the second season onwards, the writers were paid for their time in the room. This meant they did not have to pursue other parallel projects, as is often the case in the German TV fiction industry, where writers usually receive most of their clearing only for the final script. In sum, payment models are indicated that are closer to those in other markets and that might make it easier to produce transnational series content.

More directly, however, it was decisive for the transnational circulation of Deutschland that the draft scripts and linked development papers were written in English. Only at the end did Jörg Winger translate the final scripts into German. Via contacts at Fremantle, the international television content and production and distribution subsidiary of RTL Group and parent of the UFA production company, English scripts reached the British Film Institute, and eventually the American pay-TV channel SundanceTV, too. The sale to SundanceTV, announced during the Berlinale film festival, was therefore already supported by English-language scripts, although Winger claimed that from the beginning Deutschland was planned as a German series and not as a transnationally circulating one. 
Gradually, the script development of the Deutschland project appears to also have become more transnational, as new distributors and partners came on board and started giving editorial feedback, albeit to a much lesser extent than for previous German television series. These changes in the screenwriting process reflect the transnational expansion of financiers. In this context, one might discuss financescapes, to adopt Appadurai's vocabulary once more. What once was an image-building programme for the nationally operating network RTL has increasingly become subject to mixed financing from partners from different countries. SundanceTV and Hulu in the US, Canal+ in France, Sky in Italy and Channel 4 in the UK are distributors, which partly co-financed the further seasons Deutschland 86 and Deutschland 89 as well. A large part of the budget is said to have come from international sales, which were initiated by the Fremantle distribution company as part of the RTL Group. Further funds stem from the local film board Medienboard BerlinBrandenburg, which has opened up to television series, especially such ones with transnational potential, as two funding executives pointed out at an industry workshop. But the new key financier from the second season on was Amazon Prime Video. In the end, such new actors in the German TV fiction industry and transnational partners were the decisive factors for the continuation of Deutschland 83. Indeed, Winger has argued, at an industry workshop, that should the show have emerged in 2008 and not 2018, there would probably have been no second or third season.

Linked to mixed transnational financing, Deutschland additionally represents a move away from the 'buyout model', traditional in Germany, and thereby a structural change which might encourage transnational circulation. In the concluding section, I touch upon such broader issues in respect to transnational distribution.

\section{0 ut look}

To date in the German TV fiction industry, especially for series, broadcasters usually provide 100 percent financing and receive all rights as part of a so-called 'total buyout'. ${ }^{63}$ This has resulted in the self-centredness of the television market, on which, as mentioned above, some interviewees have reflected critically. Furthermore, certain hierarchies in the project-based cooperation between broadcaster, production company and creative freelancers have been a consequence of this financing pattern. ${ }^{64}$ The lack of additional income and format rights has prevented German production companies from penetrating foreign markets on the basis of successful programmes, as other competitors frequently have, Oliver Castendyk and Klaus Goldhammer suggest. ${ }^{65}$ In the interviews discussed here, it was especially Joachim Kosack who (obviously against the backdrop of the interests of UFA) emphasised revenue shares for the producers beyond the pure buyout model and, in this context, income from international distribution. In this respect, the increasingly transnationally financed period drama Deutschland may be a trendsetting model.

However, when players such as Netflix acquire all rights for an unlimited licensing period for all distributions methods and territories for a fixed price, financing processes again move in the direction of the purely commissioned production and the total buyout. ${ }^{66}$ Against this background, it is hardly surprising that at a 2019 industry workshop Jörg Winger mentioned as a recent trend in German television, besides the mixed-financing of series, productions that remain in one house, similar to the pre-1948 US studio system. For production companies, this can of course be a difficult scenario, as their scope of action is reduced rather than increased. Therefore, some interviewees indicated a critical view of Netflix. On the other hand, creatives with transnational aspirations might appreciate that, with that platform, transnational circulation is often guaranteed, and thus the chance of transnational attention increases considerably. ${ }^{67}$

In any case, it is not only the project Deutschland, with its development towards transnational mixed financing, that reveals ways in which series from Germany can go global. Netflix, an "aggressively international service", ${ }^{68}$ points to further factors that were only touched upon in the present case study, such as the release of whole seasons in several Netflix territories, in different subtitles or even dubbed versions, and often even on the same starting date. For Dark, Netflix offers a dubbed English version - another PR stunt of that non-transparent provider, as an executive producer 
of a competitor suspects, ${ }^{69}$ or a further, possibly 'trend-setting' strategy to make German series travel more comprehensively? In any case, Netflix hints at the dynamic change happening in the global media and television landscape, which one might categorise as a mediascape, interwoven with other -scapes of the global flow, to pick up on Appadurai's terminology. Transnational developments affect the German TV fiction industry. It is not least the increased transnational demand for content through streaming services that is responsible for the travel of German television series; it is arguably even more significant than the textual and production-specific factors highlighted and explored in this article and through the case study Deutschland.

However, this 1980s drama remains a fruitful example, as it helped to push the recent transnational expansion of the German TV (fiction) industry. Given the niche status of SundanceTV, the allegedly great success of Deutschland 83 in the US in 2015 was partly a construction of PR work, ${ }^{70}$ as some TV professionals lecturing at the observed industry workshop noted. Still, the miniseries was a starting point for the further transnationalisation of the German TV fiction industry and its individual actors. Edward Berger, leading director of the first season, has begun to work for the British and American industries, and Jörg Winger co-created the Romanian-German co-production Hackerville (2018) for HBO Europe and the German pay-TV channel TNT Serie. Furthermore, in 2020 he launched Big Window Productions, a new department at UFA Fiction that focuses on transnational projects (in either English or German). Anna Winger is the executive producer and co-writer of the Netflix miniseries Unorthodox (2020), which is shot in English and Yiddish, but still has personal and institutional links to the German TV industry.

The period drama Deutschland is interwoven both with corresponding changes towards transnationalisation and with German TV traditions, especially the multipart 'historical-political event film', ${ }^{71}$ which had already found distribution beyond German-speaking markets several years earlier. On the textual and on the production-specific level, Deutschland indicates reformations, for instance by narrating German history with a lighter tone through pop-cultural references and by using the showrunner and the writers' room, at least rudimentarily, in the screenwriting process.

In Germany itself, viewing figures for this slightly reformed German period drama were below RTL's expectations leading German media to regard the series as a flop after its broadcast in late $2015 .^{72}$ In respect to transnational circulation, this result is interesting as it shows that, other than in former scenarios, national success is no longer necessarily required for a German series to travel. Furthermore, the mediocre ratings point towards different tensions. The practitioners involved in Deutschland hinted especially at the gap between commercial and public-service television, which turned out to be surprisingly large, if one takes into account larger viewing figures for historical miniseries and 'event' films at ARD and ZDF (see, e.g., the UFA Fiction production Ku'damm 56/59, 2016/2018, and Generation War). Criticism regarding RTL's online distribution of Deutschland ${ }^{73}$ indicates a tension between internetbased 'catch-up' TV and 'classical' broadcasting shaped by nationally and historically grown broadcasting slots. Linked to such different concepts of television, tensions between a national and a transnational distribution also come to light. While German 'quality TV' in the shape of Deutschland functions in a transnational comparison as 'subtitled drama', and thus as niche programming, German broadcasters with their comparatively large audiences often still rely on a mainstream, mass-audience approach and on linear broadcasting. When looking at German series that travel transnationally, corresponding tensions and national framework conditions must not be overlooked.

\section{Notes}

1. "Showrunner und Antihelden - Was braucht die deutsche Serie zum Internationalen Erfolg? [Showrunners and Anti-heroes What does the German Tv series need in order to achieve international success?], panel presented by TOP: Talente and BAVARIA Film, Vertretung des Freistaates Bayern beim Bund [Representation Office of the Federal State of Bavaria], Berlin, February 9, 2015. 
2. E.g. Alan Posener, "Von jetzt an geht Fernsehunterhaltung anders" [From Now on Television Entertainment Works Differently], Die Welt, November 25, 2015, https://www.welt.de/kultur/article149229922/Von-jetzt-an-geht-Fernsehunterhaltunganders.htmlhttps://www.welt.de/kultur/article149229922/Von-jetzt-an-geht-Fernsehunterhaltung-anders.html

3. E.g. Torsten Zarges, "Die Totengräber und ihr Wunsch, höher zu fliegen" [The Gravediggers and Their Desire to Fly Higher], DWDL.de, February 11, 2015, http://www.dwdl.de/nachrichten/49682/die_totengraeber_und_ihr_wunsch_hoeher_zu_ fliegen/

4. E.g. Georg Diez and Thomas Hüetlin, "Im Zauderland" [In the Shilly-shally Land], Der Spiegel, March 28, 2013, http://www. spiegel.de/spiegel/print/d-90750511.html

5. E.g. Pierre Gras, Good bye, Fassbinder! Der deutsche Kinofilm seit 1990 [Goodbye, Fassbinder! The German Motion Picture since 1990] (Berlin: Alexander, 2014), 22-31.

6. E.g. Jonas Nesselhauf and Markus Schleich, eds., Das andere Fernsehen?!: Eine Bestandsaufnahme des 'Quality Television' [The Other Television?!: A Look at the Status Quo of 'Quality Television'] (Bielefeld: transcript, 2016); Kathi Gormász, Walter White \& Co: Die neuen Heldenfiguren in amerikanischen Fernsehserien [Walter White \& Co.: The New Hero Figures in American TV Series] (Konstanz: UVK, 2015); Robert Blanchet, ed., Serielle Formen: Von den frühen Film-Serials zu aktuellen Quality-TV- und Onlineserien [Serial Forms: From the Early Film Serials to Current Quality TV and Online Series] (Marburg: Schüren, 2010).

7. For a first analysis of the discourse on 'quality TV' series in the feature pages of German newspapers, see Meta-Kristin Koepsel, "Das deutsche Feuilleton und sein 'Quality TV' [The German Feuilleton and Its 'Quality TV'], Pop Zeitschrift, January 24, 2015, http://www.pop-zeitschrift.de/2015/01/24/das-deutsche-feuilleton-und-sein-quality-tvvon-meta-kristinkoepsel24-1-2015/

8. Florian Krauß, 'QQuality Series' and Their Production Cultures: Transnational Discourses within the German Television Industry', Series - International Journal of TV Serial Narratives 4, no. 2 (2018): 49-51, https://series.unibo.it/article/view/8282/8713

9. E.g. Stefan Stuckmann, "Wie man keine gute Serie macht" [How One Does Not Produce Good Series] stuckmann.de (blog), September 3, 2015, http://stefanstuckmann.de/?p=81

10. E.g. DJ Frederiksson [Anonymous], "Die ausbleibende Revolution" [The Missing Revolution], d-trick [blog by director and scriptwriter Dietrich Brüggemann], February 4, 2014, http://d-trick.de/wp-content/uploads/die_ausbleibende_revolution.pdf

11. Jason Mittell, Complex TV: The Poetics of Contemporary Television Storytelling (New York: New York University Press, 2015$), 90$.

12. Sarah Hughes, "Deutschland 83 Opens the Floodgate for a German TV Renaissance," Guardian, February 23, 2016, https:// www.theguardian.com/tv-and-radio/tvandradioblog/2016/feb/23/deutschland-83-opens-the-floodgate-for-a-german-tvrenaissance

13. Hanne Bruun, "The Qualitative Interview in Media Production Studies" in Advancing Media Production Research: Shifting Sites, Methods, and Politics, ed. Chris Paterson et al. (Basingstoke: Palgrave Macmillan, 2016).

14. Jörg Winger, Interview with author, May 15, 2017. All interview excerpts were translated by me.

15. Ulrike Leibfried, Interview with author, June 16, 2016. At the request of the interviewee, the conversation was not recorded; instead, it was written down by hand during the interview.

16. Joachim Kosack, Interview with author, January 29, 2019.

17. Edward Berger, Interview with author, November 26, 2018.

18. Florian Cossen, Interview with author, October 30, 2018.

19. The research project 'Quality Series' as Discourse and Practice: Self-theorizing in the German TV Series Industry, funded by Deutsche Forschungsgemeinschaft [German Research Council], University of Siegen, Germany, 2018-2021.

20. European TV Drama Series Lab and Winterclass Serial Writing and Producing, workshops, Erich Pommer Institute Potsdam, Potsdam and Berlin, 2015-2019.

21. Michael Meuser and Ulrike Nagel, "ExpertInneninterviews - vielfach erprobt, wenig bedacht: Ein Beitrag zur qualitativen Methodendiskussion" [Expert Interviews - Tried and Tested Many Times, but Little Thought Through: A Contribution to the Qualitative Discussion of Methods], in Qualitativ-empirische Sozialforschung: Konzepte, Methoden, Analysen [Qualitative Empirical Social Research: Concepts, Methods, Analysis], ed. Detlef Garz and Klaus Kraimer (Opladen: Westdeutscher Verlag, 1991)

22. Bruun, "The Qualitative Interview".

23. See, e.g., Paul McDonald, "Introduction: In Focus - Media Industry Studies," Cinema Journal 52, no. 3 (2013); Timothy Havens, Amanda D. Lotz, and Serra Tinic, "Critical Media Industry Studies: A Research Approach," Communication, Culture and Critique 2, no. 2 (2009).

24. Paul Du Gay, ed., Production of Culture, Cultures of Production: Culture, Media and Identities (London: Sage, 1997).

25. E.g. Lothar Mikos and Elizabeth Prommer, "Das Babelsberger Modell" [The Babelsberg Model], in Qualitative Medienforschung Ein Handbuch [Qualitative Media Research: A Handbook], ed. Lothar Mikos and Claudia Wegener (Konstanz: UVK, 2005). 
26. For a further discussion on the term 'transnational', see, e.g., Pamela Przybylski, Klaus-Dieter Altmeppen, Funda Güngör, M. Bjørn von Rimscha, Denis Voci, and Matthias Karmasin, "Mediale Grenzüberschreitungen: Methodische Herausforderungen der Unterscheidung von international, multinational, transnational und global in der Medienökonomie" [Crossing Media Borders: Methodological Challenges of the Distinction between International, Multinational, Transnational, and Global in Media Economics], in Methodische Zugänge zur Erforschung von Medienstrukturen, Medienorganisationen und Medienstrategien [Methodological Approaches to Research on Media Structures, Media Organisations, and Media Strategies], ed. M. Bjørn von Rimscha, Samuel Studer, and Manuel Puppis (Baden-Baden: Nomos, 2016), 218.

27. Arjun Appadurai, "Disjuncture and Difference in the Global Cultural Economy," in Media and Cultural Studies: Keyworks, ed. Meenakshi Gigi Durham and Douglas M. Kellner (Malden: Blackwell, 2006), https://we.riseup.net/assets/102142/appadurai.pdf

28. Ibid.

29. Ibid., 596

30. Lothar Mikos, "Germany as TV Show Import Market," in German Television: Historical and Theoretical Approaches, eds. Larson Powell and Robert R. Shandley (New York: Berghahn, 2016), 161-62.

31. E.g. Ben Harris, "European Television Co-productions' - An Interview with Klaus Zimmermann," in European Film and Television Co-production: Policy and Practice, eds. Julia Hammet-Jamart, Petar Mitric, and Eva N. Redvall (Cham: Springer, 2018), 319-28. For former co-productions in Europe and Germany, see also publications on the research project Eurofiction, such as Sofia Blind and Gerd Hallenberger, eds., European Co-productions in Television and Film (Heidelberg: Winter, 1996).

32. Jean K. Chalaby, "At the Origin of a Global Industry: The TV Format Trade as an Anglo-American Invention," Media, Culture \& Society 34, no. 1 (2012). For format adaptations in German TV fiction, see especially Tanja Weber, Kultivierung in Serie: Kulturelle Adaptionsstrategien von fiktionalen Fernsehserien [Cultivation in a Row: Cultural Adaptation Strategies of Fictional Television Series] (Marburg: Schüren, 2012).

33. See Gunther Kirsch, "Produktionsbedingungen von Daily Soaps: Ein Werkstattbericht" [Production Conditions of Daily Soap Operas: A Production Report], montage AV 10, no. 1 (2001): 48-52, https://www.montage-av.de/pdf/101_2001/10_1 Gunther_Kirsch_Produktionsbedingungen_von_Daily_Soaps.pdf; Nathalie Knöhr, "Neues aus der Soap Factory: Ethnografisches Forschen in der deutschen Fernsehindustrie" [News from the Soap Factory: Ethnographic Research in the German Television Industry], Navigationen 18, no. 2 (2018).

34. See also Florian Krauß, "All Is Changing": Interview with Joachim Kosack on Deutschland83 and Transformation of the German TV Series Industry," Series - International Journal of TV Serial Narratives 5, no. 1 (2019): 70, https://doi. org/10.6092/issn.2421-454X/9716

35. Paul Cooke, "Heritage, Heimat, and the German Historical 'Event Television': Nico Hoffmann's teamWorx," in Powell and Shandley, German Television.

36. Bärbel Göbel-Stolz, "Once Upon a Time: Tatort, Germany's Longest Running Police Procedural," in Powell and Shandley, German Television.

37. John Thornton Caldwell, Production Culture: Industrial Reflexivity and Critical Practice in Film and Television (Durham, NC: Duke University Press, 2008), 17.

38. Andreas Dörner, "Geschichtsfernsehen und der historisch-politische Eventfilm in Deutschland" [History Television and the Historical-Political Event Film], in Unterhaltungsrepublik Deutschland: Medien, Politik und Entertainment [Entertainment Republic Germany: Media, Politics, and Entertainment], eds. Andreas Dörner and Ludgera Vogt (Bonn: Bundeszentrale für politische Bildung, 2012).

39. For a critical discussion of the historical 'event' film or miniseries from Germany, see, e.g., Tobias Ebbrecht, "(Re)Constructing Biographies: German Television Docudrama and the Historical Bibliography," in Televising History: Mediating the Past in Postwar Europe, eds. Erin Bell and Ann Gray (Basingstoke: Palgrave Macmillan, 2010).

40. On the reception in Poland, see Magdalena Saryusz-Wolska and Carolin Piorun, "Verpasste Debatte: Unsere Mütter, Unsere Väter in Deutschland und Polen" [Missed Debates: Generation War in Germany and Poland], Osteuropa 64, nos. 11-12 (2014), https://www.zeitschrift-osteuropa.de/hefte/2014/11-12/verpasste-debatte/

41. E.g. A. O. Scott, "A History Lesson, Airbrushed," New York Times, January 14, 2014, https://www.nytimes.com/2014/01/15/ movies/generation-war-adds-a-glow-to-a-german-era.html

42. See Florian Krauß, "Teen und Quality TV: Deutschland 83 und Transformationen der deutschen Fernsehserie" [Teen and Quality TV: Deutschland 83 and Transformations of the German Television Series],. In: Krauß, Florian; Stock, Moritz (Hrsg.): Teen TV: Repräsentationen, Lesarten und Produktionsweisen aktueller Jugendserien [Teen TV: Representations, Readings, and Production Modes of Contemporary Teenager Series], ed. Florian Krauß and Moritz Stock (Wiesbaden: VS Springer, 2020) 163-183.

43. Robert C. Reimer, Reinhard Zachau, and Margit M. Sinka, German Culture through Film: An Introduction to German Cinema (Cambridge: Hackett, 2017), 244.

44. Caldwell, Production Culture, 20 (italics in the original).

45. Dörner, "Geschichtsfernsehen und der historisch-politische Eventfilm in Deutschland".

46. Gilles Fontaine and Marta Jimenez Pumares, The Production and Circulation of TV Fiction in the EU28: Television and VOD (Strasbourg: European Audiovisual Observatory, Council of Europe, 2018), 20, https://rm.coe.int/the-production-andcirculation-of-tv-fiction-in-the-eu28-television-an/1680946229 
47. Johannes F. Sievert, ed., Im Angesicht Des Verbrechens: Fernseharbeit am Beispiel einer Serie [In the Face of Crime: A Case Study on Television Work] (Berlin: Alexander, 2010).

48. Kathrin Rothemund, "KDD-Kriminaldauerdienst: Das Brüchige im Krimigenre" [KDD - Berlin Crime Squad: Breaks with the Crime Genre], in Die Lust am Genre: Verbrechergeschichten aus Deutschland [Genre Pleasure: Crime Stories from Germany], ed. Rainer Rother and Julia Pattis (Berlin: Bertz + Fischer, 2011).

49. Appadurai, "Disjuncture and Difference in the Global Cultural Economy," 596.

50. Brigitte Frizzoni, "Zwischen Trash-TV und Quality-TV: Wertediskurse zu serieller Unterhaltung" [Between Trash TV and Quality TV: Evaluation Discourses on Serial Entertainment], in Populäre Serialität: Narration - Evolution - Distinktion [Popular Seriality: Narration - Evolution - Distinction], ed. Frank Kelleter (Bielefeld: transcript, 2014), 340.

51. Neil Genzlinger, "Review: 'Deutschland 83' Focuses on a Reluctant Cold War Spy," New York Times, May 15, 2016, https:// www.nytimes.com/2015/06/16/arts/television/review-deutschland-83-focuses-on-a-reluctant-cold-war-spy.html

52. Florian Krauß, "'Quality Series” and Their Production Cultures,” 53-55.

53. See e.g. ibid. and Tilmann P. Gangloff, "Das letzte Wort: Die Film- und Fernsehbranche diskutiert über Kontrakt 18" [The Last Word: The Film and Television Industry Discusses the Writers' Initiative Kontrakt 18], TV Diskurs 22, no. 4 (2018), https://tvdiskurs.de/data/hefte/ausgabe/86/gangloff-kontrakt18-tvd86.pdf

54. Florian Krauß, "Showrunner und Writers' Room: Produktionspraktiken der deutschen Serienindustrie" [Showrunner and Writers' Room: Production Practices in the German Television Series Industry], montage AV 27, no. 2 (2018).

55. See Eva Novrup Redvall, "A European Take on the Showrunner? Danish Television Drama Production," in Behind the Screen: Inside European Production Cultures, eds. Petr Szczepanik and Patrick Vonderau (New York: Palgrave Macmillan US, 2013), 153-69; Petr Szczepanik and Eva Pjajčíková, "Group Writing for Post-socialist Television," in Production Studies, the Sequel! Cultural Studies of Global Media Industries, ed. Miranda Banks, Bridget Conor, and Vicki Mayer (London: Routledge, 2016), 105-20.

56. Edward Berger, Interview with author, January 28, 2020.

57. Jörg Winger, Interview with author, January 28, 2020.

58. Timo Gößler and Frank Weiß, “Kreativitätsindustrie: Writers Room” [Creative Industry: Writers' Room], TelevIZlon 27, no. 1 (2014): 30, https://www.br-online.de/jugend/izi/deutsch/publikation/televizion/27_2014-1/Weiss_Goessler Kreativitaetsindustrie.pdf

59. See Kirsch, "Produktionsbedingungen von Daily Soaps," 45.

60. See, e.g., the writers' room approach in the current co-production Wir Kinder vom Bahnhof Zoo (2020), the series version of the cult film Christiane F. - Wir Kinder vom Bahnhof Zoo (Christiane F., 1981) for Amazon Prime Video. See Florian Krauß, "Ich denke nie in diesen Kategorien jung, alt, vorne, hinten': Interview mit Annette Hess über Wir Kinder vom Bahnhof Zoo un aktuelle Fernsehserien aus Deutschland" ['I Never Think in Such Categories Like Young, Old, Before, Behind': Interview with the Scriptwriter Annette Hess on Wir Kinder vom Bahnhof Zoo and Contemporary Television Series from Germany], in Teen TV: Repräsentationen, Lesarten und Produktionsweisen aktueller Jugendserien [Teen TV: Representations, Readings, and Production Modes of Contemporary Teenager Series], ed. Florian Krauß and Moritz Stock (Wiesbaden: Springer VS, 2020, 207-216).

61. Patricia Phalen and Julia Osellame, "Writing Hollywood: Rooms with a Point of View," Journal of Broadcasting \& Electronic Media 56, no. 1 (2012): 8.

62. Florian Krauß, "Showrunner und Writers' Room,"105-06.

63. Christian Zabel, Wettbewerb im deutschen TV-Produktionssektor: Produktionsprozesse, Innovationsmanagement und Timing-Strategien [Competition in the German TV Production Sector: Production Processes, Innovation Management and Timing Strategies] (Wiesbaden: Springer VS, 2009), 59-60.

64. Arnold Windeler, Antje Lutz, and Claus Wirth, "Netzwerksteuerung durch Selektion: Die Produktion von Fernsehserien in Projektnetzwerken" [Network Control through Selection: The Production of Television Series in Project Networks], montage AV 10, no. 1 (2001): 115.

65. Oliver Castendyk and Klaus Goldhammer, Produzentenstudie 2018: Daten zur Film- und Fernsehwirtschaft in Deutschland 2017/2018 [Producer Study: Data on the Film and Television Industry in Germany 2017/2018] (Leipzig: Vistas, 2018), 38, https://www.hamburgmediaschool.com/assets/documents/Forschung/Produzentenstudie-2018_Web.pdf

66. Ibid., 122.

67. Florian Krauß, "Transnationale Vernetzungen in der Fernsehserien-Produktion" [Transnational Networks in TV Series Production], $t v$ diskurs (online first), 15.04.2020, https://tvdiskurs.de/beitrag/transnationale-vernetzungen-in-der-fernsehserien produktion/

68. Ramon Lobato, "Rethinking International TV Flows Research in the Age of Netflix," Television \& New Media 19, no. 3 (2018): 244.

69. Frank Jestfelder, Interview with author, November 16, 2018.

70. In the US, Deutschland 83 is said to have reached only around 70,000 to 100,000 viewers; see Timo Nöthling, "Noch keine Export-Weltmeister: So schlugen sich deutsche TV-Serien zuletzt im Ausland" [Still No Export World Champions: How German Series Have Performed Lately Abroad], quotenmeter.de, May 19, 2018, http://www.quotenmeter.de/n/101107/noch-keineexport-weltmeister-so-schlugen-sich-deutsche-tv-serien-zuletzt-im-ausland

71. Dörner, "Geschichtsfernsehen und der historisch-politische Eventfilm in Deutschland." 
72. E.g. Michael Hanfeld, "RTL-Serie 'Deutschland 83': Wieso sieht das keiner?" [RTL Serie's Deutschland 83: Why Is Nobody Watching?], Frankfurter Allgemeine Zeitung, May 31, 2016, http://www.faz.net/aktuell/feuilleton/medien/ die-rtl-serie-deutschland-83-war-hochgelobt-aber-ein-flop-13973730.html

73. See also Thomas Lückerath, "Eine Analyse der großen Enttäuschung: RTL hat bei 'Deutschland 83' viele Chancen vertan" [An Analysis of the Great Disappointment: RTL Missed Many Chances with Deutschland 83] DWDL.de, December 4, 2015, https://www.dwdl.de/meinungen/53675/rtl_hat_bei_deutschland_83_viele_chancen_vertan/

\section{Biography}

Florian Krauß, Dr. phil., head of the research project “'Quality Series' as discourse and practice: Self-theorization in the German serial industry" at the University of Siegen, Germany; previously lecturer at the department for media studies there and research associate at the Film University Babelsberg KONRAD WOLF. 2011 PhD with the thesis Bollyworld Neukölln: MigrantInnen und Hindi-Filme in Deutschland (publication 2012); co-editor of the issue 'Media industries' of the German journal Navigationen (2018); and of the anthology Teen TV (2020) further recent publications on media industry/production studies in montage AV, SERIES, Journal of Popular Television and others. 